\title{
Connexin-43 can delay early recurrence and metastasis in patients with hepatitis B-related hepatocellular carcinoma and low serum alpha-fetoprotein after radical hepatectomy
}

\author{
Zu-Sen Wang ${ }^{1}$, Li-Qun Wu ${ }^{1 *}$, Xin Yi ${ }^{1}$, Chao Geng ${ }^{1}$, Yu-Jun $\mathrm{Li}^{2}$ and Ru-Yong Yao ${ }^{3}$
}

\begin{abstract}
Background: We studied the relationships among Cx43, CD105, and VEGF in specimens of hepatitis B virus (HBV)-related hepatocellular carcinoma (HCC) with different serum AFP levels with respect to recurrence and metastasis.

Methods: Expressions of Cx43, CD105, and VEGF in 234 HCC tissue specimens were examined using tissue microarray and immunohistochemistry. Cx43 mRNA expression was examined in 38 frozen HCC specimens using RT-PCR. Correlations between these expressions and tumor recurrence, metastasis, and prognosis were analyzed using Kaplan-Meier and Cox regression analyses.

Results: $C \times 43$ expression correlated with early tumor recurrence $(P=0.001)$, disease-free survival $(P=0.026)$, and overall survival $(P=0.000)$ in patients with serum AFP $<400 \mathrm{ng} / \mathrm{ml}$, but not in those with serum AFP $\geq 400 \mu \mathrm{g} / \mathrm{L}$. Cx43 expression is an independent predictor of later recurrence and longer overall survival and is inversely correlated with expression of CD105 and VEGF ( $P=0.018$ and 0.023 , respectively), histological differentiation $(P=0.002)$, vessel tumor embolism $(P=0.029)$, and focal number $(P=0.017)$. Immunohistochemistry showed that Cx43 expression in patients with low AFP was lower in patients with distant metastases than in those with no metastasis or those with liver metastasis. Patients with early recurrence expressed less CX43 mRNA than did those with no recurrence $\left(X^{2}=9.827, P=0.002\right)$.
\end{abstract}

Conclusions: $\mathrm{Cx} 43$ expression can delay early HCC recurrence, metastasis, and poor prognosis after radical hepatectomy in patients with HBV-related HCC and low AFP.

Keywords: Carcinoma, Hepatocellular, Hepatitis B, Alpha-fetoprotein, CX43, VEGF, CD105, Early recurrence, Metastasis, Prognosis

\section{Background}

Hepatocellular carcinoma (HCC) is the sixth most common cancer and the third most common cause of cancer death [1]. An estimated 748,300 new liver cancer cases and 695,900 cancer deaths occurred worldwide in 2008 [2]. Although an increasing number of new methods are now applied to treat these patients, surgery (including hepatectomy and liver transplantation) is still the most

\footnotetext{
*Correspondence: wulq5810@126.com

1 Department of Hepatobiliary Surgery, Affiliated Hospital of Medical College Qingdao University, Qingdao, Shandong Province 266003, China Full list of author information is available at the end of the article
}

important therapeutic approach for patients with HCC [3]. Transplantation is the preferred treatment option for small and resectable HCC [4], but its use is limited by the lack of donor organs [5]. Although appropriate selection of patients with HCC increases the clinical survival benefit after radical liver resection [6], the prognosis of HCC remains poor because of the high rate of recurrence and metastases after radical resection $[7,8]$. A primary research focus involves how to decrease the HCC recurrence and metastasis rates worldwide.

Chronic hepatitis B virus (HBV) and hepatitis C virus (HCV) infections induce approximately $75-80 \%$ of $\mathrm{HCC}$

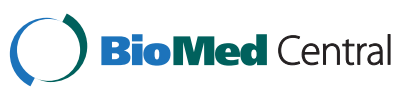


in the world [9]. Chronic HBV infection accounts for about $60 \%$ of the total liver cancer in developing countries and about $23 \%$ of the cancer in developed countries. This infection results in approximately one-third of all cases of liver cirrhosis and more than three-quarters of all cases of HCC worldwide [10]. Serious endemicity of HBV infection is present in China. In a literature review, Han et al. [11] reported that a high serum viral load is the most reliable indicator of viral replication in predicting development of HCC (serum viral load of $\geq 10^{4}$ copies $/ \mathrm{mL}$ for HCC occurrence and $10^{4}$ copies $/ \mathrm{mL}$ for a poor prognosis). In addition, HBV genotype $\mathrm{C}$ is closely associated with HCC in cirrhotic patients aged $\geq 50$ years, whereas genotype $\mathrm{B}$ is associated with development of $\mathrm{HCC}$ in noncirrhotic young patients (<50 years) and postoperative relapse of HCC. Thus, we confined our investigation of $\mathrm{HCC}$ to patients with $\mathrm{HBV}$-related $\mathrm{HCC}$ (HBV-HCC) to reduce possible confounding variables, and we plan to study the relationship between and mechanisms of early recurrence of HCC and HBV-related factors (e.g., serum HBV viral load and HBV genotype and mutations).

Connexin-43 is a member of the connexin (Cx) protein family, which forms the basis of gap junctions (GJs). GJs provide a medium through which GJ intercellular communication (GJIC) is expressed; GJs are largely formed by $\mathrm{Cx}$ proteins. In liver tissue, GIIC mainly involves three kinds of $\mathrm{Cx}-\mathrm{Cx} 26, \mathrm{Cx} 32$, and $\mathrm{Cx} 43-$ whose distribution depends on cell type and location in the liver lobule [12]. HCC cells typically express high levels of Cx43, low levels of $\mathrm{Cx} 32$, and no Cx26. Cx43, which is clearly expressed in HCC cells, is mainly located in the cytoplasm; a small amount is located in areas connecting nonadjacent cells on the cell membrane, which disrupts GIIC [13].

In this retrospective study, the protein expressions of Cx43, VEGF, and CD105 in HCC tissue with different serum AFP levels were examined by tissue microarray and immunohistochemical staining; expression of $C x 43$ mRNA was examined by RT-PCR to explore the relationship between $\mathrm{Cx} 43$ and early recurrence, metastasis, and prognosis in patients with $\mathrm{HCC}$ after radical resection.

\section{Methods}

\section{Patients}

Samples were taken from 249 patients with HBV-HCC who underwent radical resection from January 2003 to December 2008 at the affiliated hospital of the Medical College of Qingdao University. The study protocol was approved by the Ethics Committee of the Qingdao University. All patients signed an informed consent form and met the medical ethics requirements. Of these, 15 who underwent preoperative transcatheter arterial chemoembolization were excluded; of the remaining 234 patients, 199 were male and 35 were female, with an average age of 54.2 years (range: $15-82$ years). According to the TNM classification (AJCC 7th edition, 2009), 137 patients were at Stage I, 30 were at Stage II, 63 were at Stage III, and 4 were at Stage IV. Control specimens were from adjacent noncancerous tissue within $2 \mathrm{~cm}$ from the incisal margin (81 cases), and intraoperative biopsies were from patients with portal hypertension (79 cases). Specimens from 38 patients with HBV-HCC who underwent radical resection from January 2011 to June 2011 were frozen by liquid nitrogen immediately and cryopreserved at ${ }^{-} 80^{\circ} \mathrm{C}$.

\section{Tissue microarray and immunohistochemistry}

A tissue arrayer (HT-1,beijing,china) was used to make $42(6 \times 7) \quad 4-\mu \mathrm{m}$-thick lattice arrays, which were first stained with hematoxylin/eosin to confirm the tissue type and then immunohistochemically stained using PV6000 methods (two steps), following the manufacturer's instructions. Briefly, PBS replaced the primary antibody as the negative control; positive tissues were used as positive controls. Rabbit anti-human Cx43, VEGF, and CD105 monoclonal antibodies as well as immunohistochemical detection reagents were purchased from ZSGB-Bio Company (Beijing, China).

\section{$R T-P C R$}

RNAiso Plus and the PrimeScript RT-PCR Kit were produced by Takara Dalian (Dalian, China). PCR Amplifier was produced by Eppendorf Company (Hamburg, Germany). The gel electrophoresis apparatus was produced by VILBER LOURMAT Company (Marne-la-Vallee, France). Primers were designed using Primer 3 and synthesized by BGI Company (Shenzhen, China). Primer sequences of $\mathrm{Cx} 43$ were as follows: forward: 5'GGCTGCTCCTCACCAACGGCC-3'; reverse: 5'-AGG TCATCAGGCCGAGGTCTG-3'. Total RNA isolation was performed according to the instructions of RNAiso Plus; reverse transcription was performed according to instructions of the PrimeScript RT-PCR Kit with a total volume of $20 \mu \mathrm{l}$. The PCR reaction took place in a total volume of $20 \mu \mathrm{l}$ using cDNA $0.5 \mu \mathrm{l}$, forward primer $0.5 \mu \mathrm{l}$, reverse primer $0.5 \mu \mathrm{l}$, Premix TAQ $12.5 \mu \mathrm{l}$, and RNA-free $\mathrm{H}_{2} \mathrm{O} 6 \mu$ l. PCR was performed at $95^{\circ} \mathrm{C}$ for $5 \mathrm{~min}$; followed by 37 cycles of $95^{\circ} \mathrm{C}$ for $30 \mathrm{~s}, 58^{\circ} \mathrm{C}$ for $30 \mathrm{~s}$, and $72^{\circ} \mathrm{C}$ for $35 \mathrm{~s}$; and a final extension of $72^{\circ} \mathrm{C}$ for $10 \mathrm{~min}$. Amplified products of Cx43 were $332 \mathrm{bp}$ long.

\section{Immunohistochemistry}

Two pathologists graded the specimens in a double-blind manner. Brown granules in the cytoplasm were considered positive for $\mathrm{Cx} 43$, and those in the cell membrane were considered positive for $\mathrm{CD} 105 ; 100$ tumorous and nontumorous hepatic cells were counted in each high-power field, and 5 fields were observed for each array. The average percentages of positive cells were then calculated. A 
specimen was considered $\mathrm{Cx} 43^{+}$if $\geq 5 \%$ of cells were positive. The CD105 microvessel density (MVD) refers to the Weidner method [14]. A specimen was considered $\mathrm{VEGF}^{+}$ if $\geq 50 \%$ of cells were positive. Cells were considered $\mathrm{CD} 105^{+}$if they were beyond the MVD-CD105 mean line.

\section{PCR products}

We assessed the amplified RT-PCR products by electrophoresing $10 \mu \mathrm{l}$ in a $2 \%$ agarose gel containing ethidium bromide $(0.5 \mathrm{mg} / \mathrm{ml})$ in $0.04 \mathrm{M}$ Tris-acetate and 0.001 M EDTA (TAE) buffer at $120 \mathrm{~V}$ for $30 \mathrm{~min}$. Gels were then developed by a UV transilluminator, and the results were scanned by a computer.

\section{Follow-up}

Patients were followed up monthly for 3 months and every 3 months thereafter. The blood alpha-fetoprotein (AFP) level, liver function, abdominal ultrasound or $\mathrm{CT}$, and chest CT were monitored at each follow-up. Patients who did not come in for appointments received follow-up calls and were followed until 31 December 2011 or until death. Tumors were considered to have recurred based on their appearance by imaging examination (abdominal ultrasound, CT, or MRI); hepatic arteriography or biopsy was used in unclear cases. Early recurrence was defined as recurrence within 1 year.

\section{Statistical analysis}

All data were analyzed using SPSS statistical software (ver. 13.0; SPSS Inc., Chicago, IL). Categorical variables were compared by the $x^{2}$ test and Pearson's correlation analysis. Survival analysis was calculated with the Kaplan-Meier method and compared using the log-rank test. Multivariate analyses were performed using a Cox proportional hazards model to identify independent prognostic factors. A $P$ value of $<0.05$ was considered statistically significant.

\section{Results}

\section{Survival analysis}

The clinicopathologic characteristics of 234 patients with HBV-HCC are summarized in Table 1. A total of 159 (67.9\%) patients had a serum AFP level of $<400 \mu \mathrm{g} / \mathrm{l}$ (low AFP) and 75 (32.1\%) had a serum AFP level of $\geq 400 \mu \mathrm{g} / \mathrm{l}$ (high AFP). The disease-free survival (DFS) for the low AFP and high AFP groups was 31.64 and 13.8 months, respectively $\left(X^{2}=4.403, P=0.036\right)$, and the overall survival rate (OS) was 84.0 and 58.55 months, respectively $\left(X^{2}=\right.$ $2.588, P=0.108$ ). The early recurrence rate was $27.0 \%$ (43 cases) and 49.3\% (37 cases), in the low AFP and high AFP groups respectively $\left(X^{2}=11.253, P=0.001\right)$.

\section{Cx43, CD105, and VEGF expression in HBV-HCC tissues and adjacent or cirrhotic tissues}

$\mathrm{Cx} 43$ appeared in the cytoplasm as brown granules. The total $\mathrm{Cx}_{43} 3^{+}$rate was $42.3 \%(99 / 234)$ in HCC tissues (Figure 1), 72.8\% (59/81) in adjacent tissues, and 92.4\% $(73 / 79)$ in cirrhotic tissues.

The $\mathrm{Cx}_{43} 3^{+}$rate was $49.1 \%(78 / 159)$ in the low-AFP group and $28 \%(21 / 75)$ in the high-AFP group, showing a significant difference $\left(X^{2}=9.257, P=0.002\right)$.

Table 1 Clinicopathological characteristics of 234 patients with HBV-related HCC

\begin{tabular}{|c|c|c|c|}
\hline \multirow{2}{*}{ Characteristics } & \multicolumn{3}{|c|}{ Result } \\
\hline & All cases & Cx43 ${ }^{+}$Group & Cx43- Group \\
\hline Gender (male/female) & $199 / 35$ & $90 / 9$ & $109 / 26$ \\
\hline Mean age (range), years & $54.2(15-82)$ & $55.1(24-82)$ & $55.5(15-74)$ \\
\hline Preoperative serum AFP $(<400 / \geq 400$ ng/mL) & $159 / 75$ & $78 / 21$ & $81 / 54$ \\
\hline Tumor size $(\leq 5 />5 \mathrm{~cm})$ & $116 / 118$ & $52 / 47$ & $64 / 71$ \\
\hline Edmondson-Steiner classification (I/II/II/I & 25/134/11/64 & $15 / 64 / 4 / 16$ & 10/70/7/48 \\
\hline Foci number $(1 />1)$ & $203 / 31$ & $79 / 20$ & $124 / 11$ \\
\hline Liver capsule invasion (yes/no) & $163 / 71$ & $62 / 37$ & $101 / 34$ \\
\hline Satellite foci (yes/no) & $31 / 203$ & $13 / 86$ & $18 / 117$ \\
\hline TNM stage $(I / I / / I I / I \zeta)$ & $137 / 30 / 63 / 4$ & $58 / 17 / 23 / 1$ & $79 / 13 / 40 / 3$ \\
\hline Cirrhosis (yes/no) & $213 / 21$ & $88 / 11$ & $125 / 10$ \\
\hline Vascular tumor thrombosis (yes/no) & $26 / 208$ & $9 / 90$ & $17 / 118$ \\
\hline Child-Pugh class (A/B) & $228 / 6$ & $98 / 1$ & $130 / 5$ \\
\hline ALB $(>35 / \leq 35 \mathrm{~g} / \mathrm{L})$ & 215/19 & $92 / 7$ & $123 / 12$ \\
\hline Tbil () & $193 / 41$ & $85 / 14$ & $108 / 27$ \\
\hline $\operatorname{ALT}(\leq 60 />60 \cup / L)$ & $165 / 69$ & $78 / 21$ & $87 / 48$ \\
\hline $\operatorname{AST}(\leq 42 />42 \mathrm{U} / \mathrm{L})$ & $157 / 77$ & $74 / 25$ & $83 / 52$ \\
\hline 1-year recurrence (yes/no) & $80 / 154$ & $24 / 75$ & $56 / 79$ \\
\hline
\end{tabular}




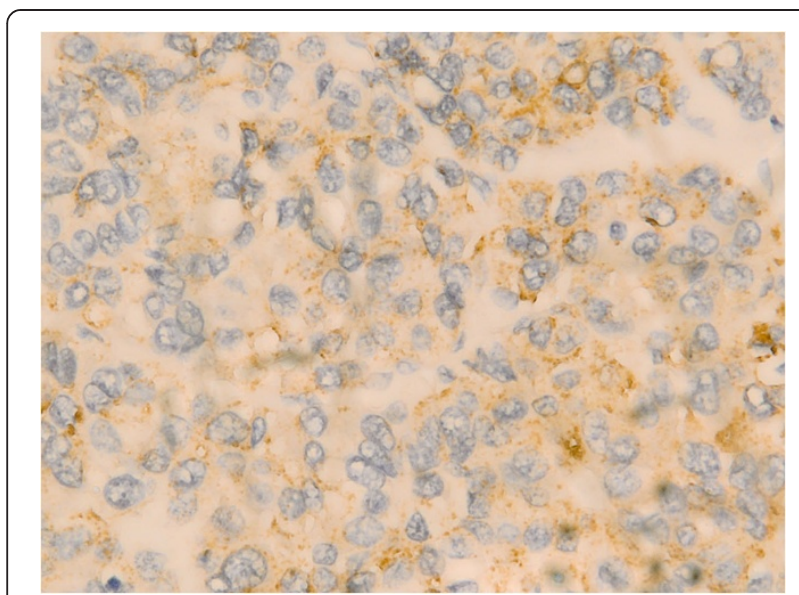

Figure 1 Positive expression of Cx43 in HCC tissues (400x).

CD105 and VEGF were partly expressed in the cytoplasm as brown granules (Figures 2 and 3). The median MVD-CD105 was 19.0, and the positive $\mathrm{CD} 105^{+}$rate was $35.8 \%$ (57/159). The $\mathrm{VEGF}^{+}$rate was $88.7 \%$ (141/159).

The $38 \mathrm{HCC}$ specimens preserved in ${ }^{-} 80^{\circ} \mathrm{C}$ were analyzed by RT-PCR, which showed a $\mathrm{C} x 43^{+}$mRNA expression rate of $57.9 \%(22 / 38)$ (Figure 4$)$.

\section{Relationship among serum AFP level, Cx43 expression, and patient prognosis}

Kaplan-Meier analysis (log rank test) showed that although the DFS of the $\mathrm{Cx} 43^{+}$group was higher than that of the $\mathrm{Cx} 43^{-}$group (medians: 33.57 and 19.36 months, respectively), there was no statistical significance. The OS of the $\mathrm{Cx} 43^{+}$group was significantly higher than that of the $\mathrm{Cx} 43^{-}$group $(P=0.023)$. Cx43- expression in patients with HCC with a low AFP level was significantly associated with a high early recurrence rate and poor prognosis (Table 2), unlike patients with HCC with a high AFP level.

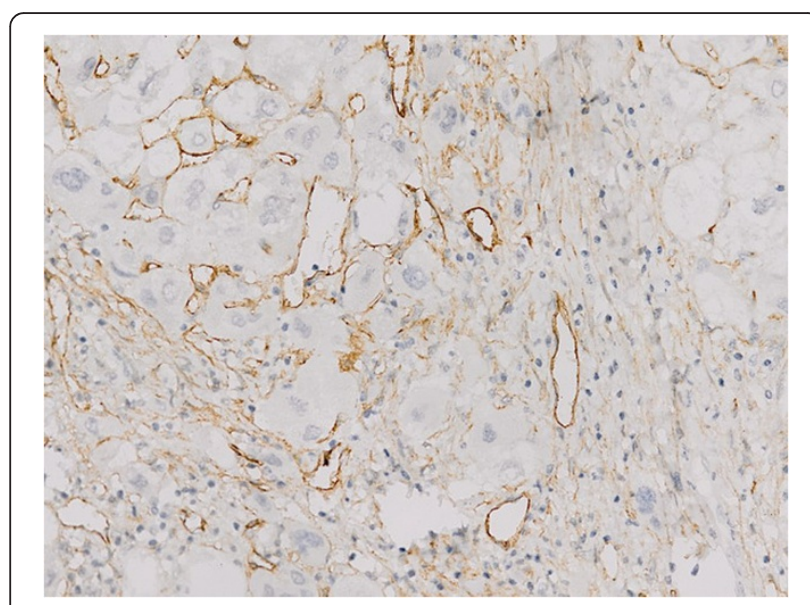

Figure 2 Positive expression of CD105 in HCC tissues (400x).

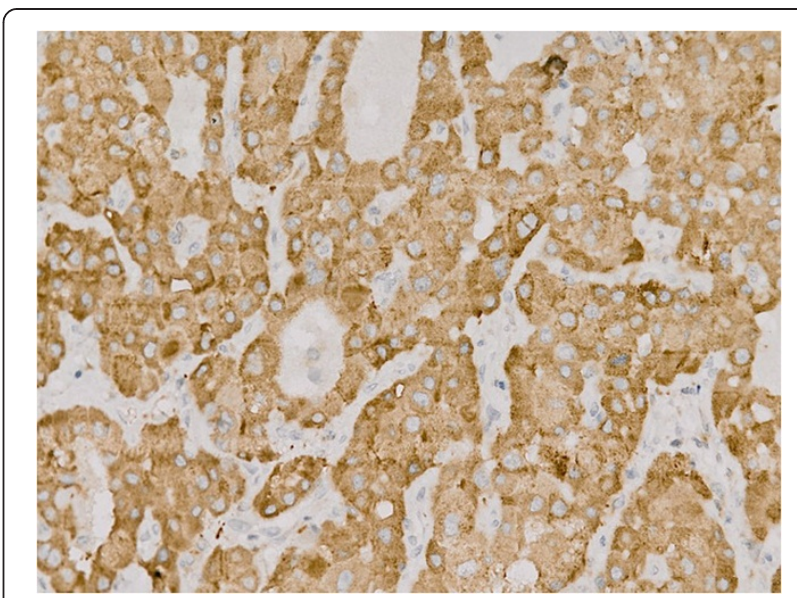

Figure 3 Positive expression of VEGF in HCC tissues (400x).

These results indicate that for patients with $\mathrm{HCC}$ with a low AFP level, $\mathrm{Cx} 43^{-}$expression is a likely predictor of early recurrence and a poor prognosis.

\section{Cx43 and clinicopathological features among patients with a low AFP level}

Chi-square tests showed that $\mathrm{Cx} 43$ expression was significantly related to histological differentiation $(P=0.023)$, multiple foci $(P=0.017)$, vascular tumor thrombosis $(P=$ $0.001)$, and early recurrence $(P=0.006)$ (Table 3$)$.

\section{Expression of $\mathrm{C} x 43$ protein and metastasis location with low AFP level}

Among patients with HBV-HCC and a low AFP level, the $\mathrm{C} \times 43^{+}$rate in the group with distant metastases was lower than that in patients with no metastases or liveronly metastases (both $P<0.05$ ) (Table 4 ).

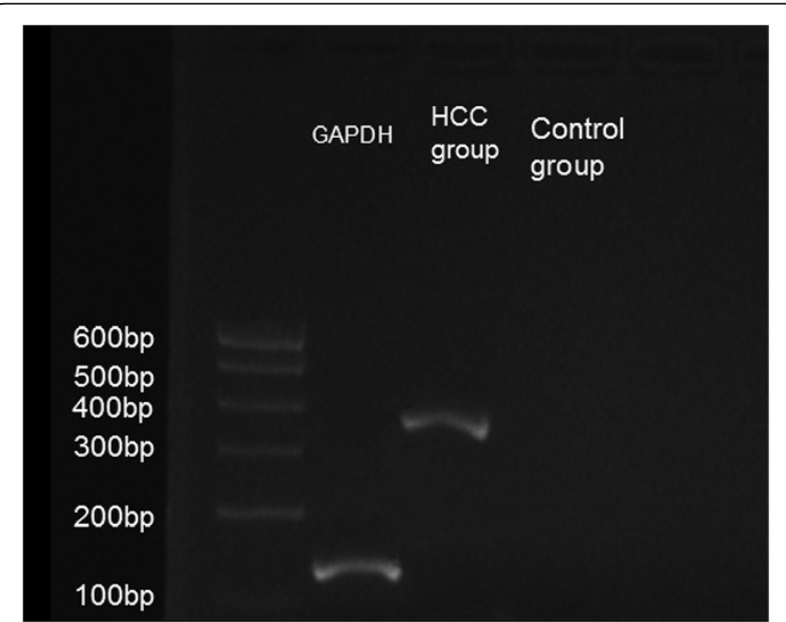

Figure 4 Expression of Cx43 mRNA in HCC tissues. 
Table 2 Correlation of high and low serum AFP levels and Cx43 expression with prognoses of patients with HBV-HCC who underwent radical resections

\begin{tabular}{|c|c|c|c|c|c|c|c|c|}
\hline & \multirow{2}{*}{$\begin{array}{c}\text { Cx43 } \\
\text { expression }\end{array}$} & \multirow{2}{*}{$\mathbf{n}$} & \multicolumn{3}{|c|}{ DFS } & \multicolumn{3}{|c|}{ OS } \\
\hline & & & Median (m) & $x^{2}$ & $P$ Value & Median $(\mathrm{m})$ & $x^{2}$ & $P$ Value \\
\hline \multirow{2}{*}{ Low AFP } & + & $78(23.3 \%)$ & 44.00 & \multirow{2}{*}{4.963} & \multirow{2}{*}{$0.026^{*}$} & 84.00 & \multirow{2}{*}{14.148} & \multirow{2}{*}{$0.000^{*}$} \\
\hline & - & $81(34.6 \%)$ & 20.12 & & & 42.74 & & \\
\hline \multirow{2}{*}{ High AFP } & + & $21(9.0 \%)$ & 11.45 & \multirow{2}{*}{1.721} & \multirow{2}{*}{0.190} & 54.03 & \multirow{2}{*}{0.012} & \multirow{2}{*}{0.912} \\
\hline & - & $54(23.1 \%)$ & 16.80 & & & 61.99 & & \\
\hline \multirow{2}{*}{ Total } & + & $99(42.3 \%)$ & 33.57 & \multirow{2}{*}{2.440} & \multirow{2}{*}{0.118} & 84.00 & \multirow{2}{*}{10.657} & \multirow{2}{*}{$0.001^{*}$} \\
\hline & - & $135(57.7 \%)$ & 19.36 & & & 47.97 & & \\
\hline
\end{tabular}

${ }^{* P}<0.05$.

Table 3 Relationship between Cx43 expression and clinicopathological factors in patients with HBV-HCC and low AFP levels

\begin{tabular}{|c|c|c|c|c|c|}
\hline & & \multicolumn{2}{|c|}{ Cx43 } & \multirow{2}{*}{$x^{2}$} & \multirow{2}{*}{$\begin{array}{c}P \\
\text { Value }\end{array}$} \\
\hline & & - (\%) & $+(\%)$ & & \\
\hline \multirow[t]{2}{*}{ Gender } & Male & $68(42.3 \%)$ & $71(44.6 \%)$ & \multirow{2}{*}{1.809} & \multirow{2}{*}{0.179} \\
\hline & Female & $13(8.2 \%)$ & $7(4.4 \%)$ & & \\
\hline \multirow[t]{2}{*}{ Age } & $>60 y$ & $18(11.3 \%)$ & $27(17.0 \%)$ & \multirow{2}{*}{3.008} & \multirow{2}{*}{0.083} \\
\hline & $\leq 60 y$ & $63(39.6 \%)$ & $51(32.1 \%)$ & & \\
\hline \multirow[t]{2}{*}{ Edmondson-Steiner classification } & $|-| \mid$ & $51(32.1 \%)$ & $66(41.5 \%)$ & \multirow{2}{*}{9.969} & \multirow{2}{*}{0.002} \\
\hline & III-IV & $30(18.9 \%)$ & $12(7.5 \%)$ & & \\
\hline \multirow[t]{2}{*}{ Foci } & Single & $64(40.3 \%)$ & $72(45.3 \%)$ & \multirow{2}{*}{5.68} & \multirow{2}{*}{$0.017^{+}$} \\
\hline & Multiple & $17(10.7 \%)$ & $6(3.7 \%)$ & & \\
\hline \multirow[t]{2}{*}{ Tumor size } & $>5 \mathrm{~cm}$ & $41(25.8 \%)$ & $48(30.1 \%)$ & \multirow{2}{*}{1.923} & \multirow{2}{*}{0.166} \\
\hline & $\leq 5 \mathrm{~cm}$ & $40(25.2 \%)$ & $30(18.9 \%)$ & & \\
\hline \multirow[t]{2}{*}{ Liver capsule invasion } & No & $24(15.1 \%)$ & $32(20.1 \%)$ & \multirow{2}{*}{2.262} & \multirow{2}{*}{0.133} \\
\hline & Yes & $57(35.8 \%)$ & $46(28.9 \%)$ & & \\
\hline \multirow[t]{2}{*}{ Satellite foci } & No & $73(45.9 \%)$ & 73(45.9\%) & \multirow{2}{*}{0.636} & \multirow{2}{*}{0.425} \\
\hline & Yes & $8(5.0 \%)$ & $5(3.2 \%)$ & & \\
\hline \multirow[t]{2}{*}{ Cirrhosis } & No & $4(2.5 \%)$ & $10(6.3 \%)$ & \multirow{2}{*}{3.075} & \multirow{2}{*}{0.080} \\
\hline & Yes & $77(48.4 \%)$ & $68(42.8 \%)$ & & \\
\hline \multirow[t]{2}{*}{ Vascular tumor thrombosis } & No & $75(47.1 \%)$ & 78(49.1\%) & \multirow{2}{*}{8.243} & \multirow{2}{*}{0.029} \\
\hline & Yes & $6(3.8 \%)$ & $0(0 \%)$ & & \\
\hline \multirow[t]{2}{*}{ Microvascular invasion } & No & $21(27.3 \%)$ & $30(40 \%)$ & \multirow{2}{*}{5.422} & חحתم \\
\hline & Yes & $18(23.4 \%)$ & $8(10.3 \%)$ & & 0.020 \\
\hline Child-Pugh class & A & $78(49.1 \%)$ & $78(49.1 \%)$ & & 0246 \\
\hline & B & $3(1.8 \%)$ & $0(0 \%)$ & 4.102 & 0.240 \\
\hline TNM Stage & $|-| \mid$ & $79(49.7 \%)$ & 78(49.1\%) & 1057 & 040 \\
\hline & ||$I-I V$ & $22(13.8 \%)$ & $12(7.6 \%)$ & t. & 0.705 \\
\hline 1-year recurrence & No & $50(31.4 \%)$ & $66(41.5 \%)$ & & O \\
\hline & Yes & $31(19.5 \%)$ & $12(7.6 \%)$ & 7.544 & $0.006^{\star}$ \\
\hline
\end{tabular}

${ }^{*} P<0.05$. The HBV-HCC database of microvascular invasion was from 1 January 2008 to 31 December 2008; 87 patients entered the statistical analysis. 
Table 4 Relationship between Cx43 expression and recurrence location in patients with $\mathrm{HBV}-\mathrm{HCC}$ and serum AFP of $<400 \mu \mathrm{g} / \mathrm{l}$

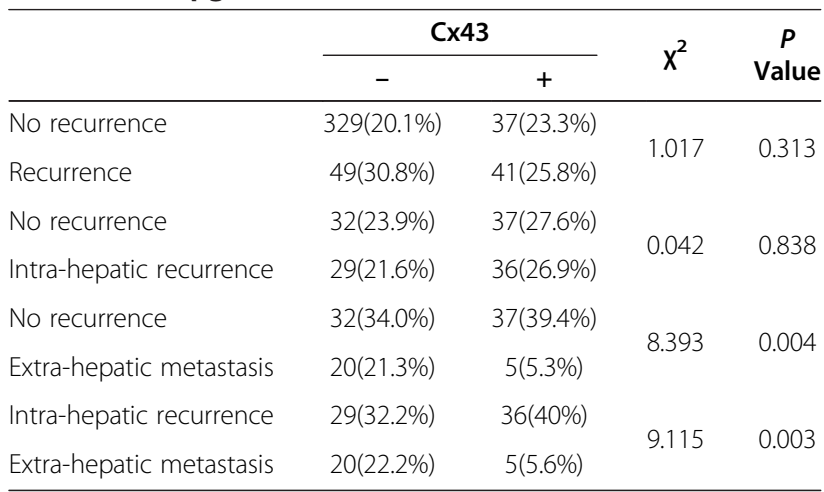

Cx43 mRNA expression and early recurrence with low AFP level

Cx43 mRNA was analyzed in 38 specimens from patients with HBV-HCC and a low AFP level, whose early recurrence rate was $26.7 \%$; of these specimens, the $C x 43$ $\mathrm{mRNA}^{+}$rate was $57.9 \%$. The early recurrence rate was lower in the $C x 43$ mRNA $^{+}$group than in the Cx43 mRNA $^{-}$group $\left(X^{2}=9.827, P=0.002\right)$ (Table 5$)$.

\section{Relationship between Cx43 expression and VEGF and CD105 expression}

Expression of MVD-CD105 and VEGF was lower in the $\mathrm{Cx} 43^{+}$group than in the $\mathrm{C} 43^{-}$group in $\mathrm{HCC}$ specimens with a low AFP level (both $P<0.05$ ) (Table 6).

\section{Expression of Cx43 protein and prognosis with a low AFP} level

In patients with HBV-HCC and a low AFP level, the early recurrence rate in the $\mathrm{Cx} 43^{+}$group was significantly lower than that in the $\mathrm{Cx} 43^{-}$group (14\% and $36 \%$, respectively; $\left.X^{2}=10.96, P=0.001\right)$. The median DFS in the $\mathrm{Cx} 43^{+}$ group (44.0 months) was longer than that in the $\mathrm{Cx} 43^{-}$ group (20.1 months; $X^{2}=4.963, P=0.026$ ) (Figures 5 and 6). The median OS in the Cx43- group (42.7 months) was significantly shorter than in the $\mathrm{Cx} 43^{+}$group (84 months; $X^{2}=14.15, P=0.000$ ) (Figure 7 ). Cox regression analysis showed $\mathrm{Cx} 43^{+}$expression to be an independent predictor of later recurrence $(P=0.042)$ and longer survival $(P=$ 0.028) (Table 7).

Table 5 Relationship between Cx43 mRNA expression and early recurrence in patients with HBV-HCC and serum AFP of $<400 \mu \mathrm{g} / \mathrm{l}$

\begin{tabular}{|c|c|c|c|c|}
\hline & \multicolumn{2}{|c|}{ Cx43 mRNA } & \multirow{2}{*}{$x^{2}$} & \multirow{2}{*}{$\begin{array}{c}P \\
\text { Value }\end{array}$} \\
\hline & + & - & & \\
\hline Non recurrence & $19(50 \%)$ & $6(15.8 \%)$ & \multirow{2}{*}{9.827} & \multirow{2}{*}{0.002} \\
\hline Early recurrence & $3(7.9 \%)$ & $10(26.3 \%)$ & & \\
\hline
\end{tabular}

Table 6 Relationship among expressions of MVD-CD105, VEGF, and CX43 in HCC specimens with serum AFP of $<400 \mu \mathrm{g} / \mathrm{l}$

\begin{tabular}{|c|c|c|c|c|}
\hline & \multicolumn{2}{|c|}{ Cx43 } & \multirow{2}{*}{$\begin{array}{c}F \\
\text { value }\end{array}$} & \multirow{2}{*}{$\begin{array}{c}P \\
\text { value }\end{array}$} \\
\hline & + & - & & \\
\hline MVD-CD105 & 19.36 & 25.84 & 5.184 & 0.018 \\
\hline VEGF + mean & 76.38 & 80.00 & 5.309 & 0.023 \\
\hline
\end{tabular}

\section{Discussion}

Although surgical techniques have improved in recent years, the high recurrence rate of $\mathrm{HCC}$ after radical resection is an obstacle to survival. Previous research has shown that the 5-year survival rate of HCC can exceed $50 \%$ after radical resection. However, the tumor recurrence rate exceeds $70 \%$ at 5 years [3] and the small HCC recurrence rate is approximately $43.5 \%$ [15] despite the fact that the early occurrence rate is approximately $63.5 \%$ [16]. Our research showed an early recurrence rate of $32 \%$ and a 5 -year recurrence rate of $61 \%$.

In 1966, Loewenstein and Kanno first reported a relationship between GJs and cancer that established a lack of electrical coupling in rat hepatomas [17]. This phenomenon was observed in both chemically induced hepatomas and Morris and Novikoff's transplanted hepatomas in rats $[18,19]$.

Today, the hypothesis associating a lack of or diminished GJs with liver cancer is still valid [17] and continues to develop with new emerging concepts such as the possible involvement of stem cells and their GIIC capacity in carcinogenesis [20]. A literature review [17] described associations among how intercellular communication is involved in the carcinogenesis process, expression of connexin (including Cx26, Cx32, and Cx43), and particular stages of liver cancer progression by in vitro and in vivo data analyses.

Alpha-fetoprotein is synthesized by fetal hepatocytes; its seroprevalence in patients with $\mathrm{HCC}$ is nearly $70 \%$. Because of its high specificity and convenient detection, AFP is a reliable index for screening, early diagnosis, and postoperative observation in patients with HCC. A low AFP level is also an important reference index for the CLIP score system. Because patients with HCC and a serum AFP level of $\geq 400 \mu \mathrm{g} / \mathrm{l}$ reportedly have significantly shorter survival times than patients with lower serum AFP levels [21], we used a serum AFP level of $400 \mu \mathrm{g} / \mathrm{l}$ as a boundary to divide patients with HCC into two groups: those with a high AFP level and those with a low AFP level.

We found that in patients with a low AFP level, $\mathrm{C} \times 43^{+}$ tumor tissues were an independent predictor of later recurrence and a better prognosis. However, there was no relationship between $\mathrm{Cx} 43^{+}$expression and postoperative recurrence or prognosis in patients with a high AFP 


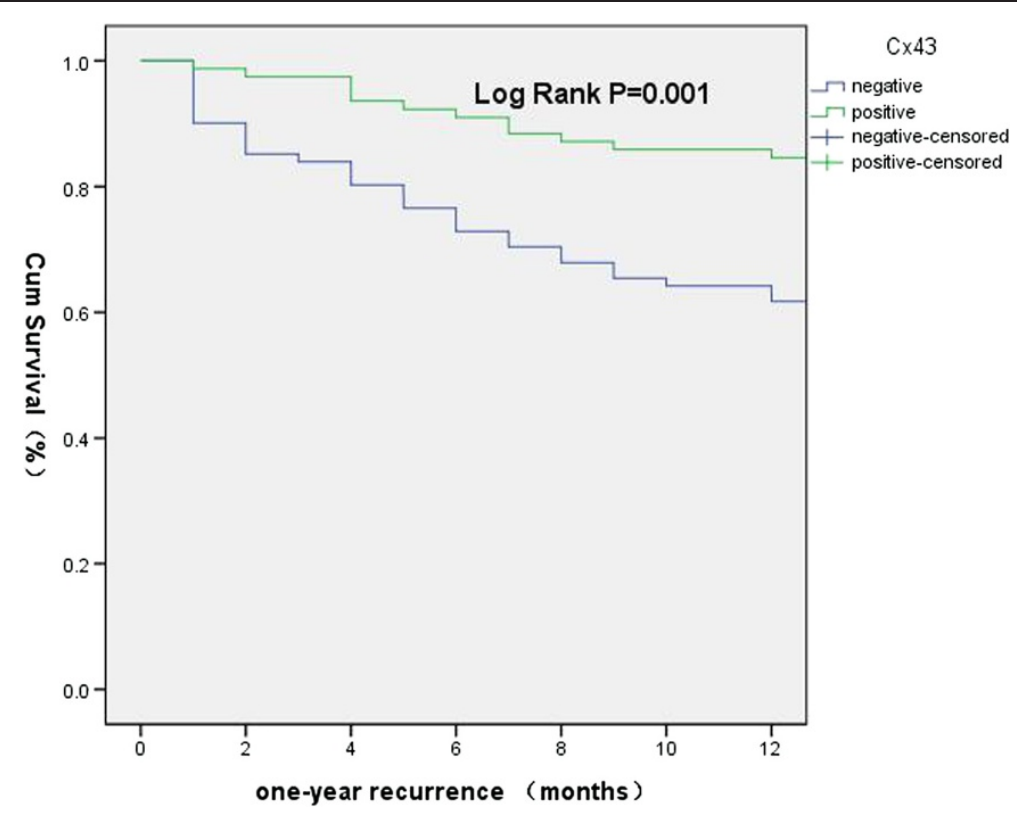

Figure 5 Early recurrence disease-free survival curves.

level. xTherefore, $\mathrm{Cx} 43^{+}$expression is an important predictor of later recurrence and a better prognosis in patients with a low AFP level who undergo radical hepatectomy.

Our results also showed that although Cx43 is mainly expressed in HCC cytoplasm (49.1\%), this expression is lower than in paracancerous tissue $(72.8 \%)$ and cirrhosis tissue (92.4\%). We also found that $C x 43$ mRNA is expressed in HCC tissue using the RT-PCR method.
Ma et al. [22] investigated 61 cases of $\mathrm{HCC}$ and 14 cases of normal liver tissues by immunohistochemical and in situ hybridization methods. The results indicated that the aberrant location of $\mathrm{Cx} 43$ protein could be responsible for the progression of hepatocarcinogenesis, and the mechanism may involve defects of $\mathrm{Cx}$ genes in post-translational processing. Ionta et al. used $C \times 43$ cDNA transfection to culture rabbit $\mathrm{HCC}$ cells in vitro and discovered that $\mathrm{Cx} 43$ reduced the multiplication

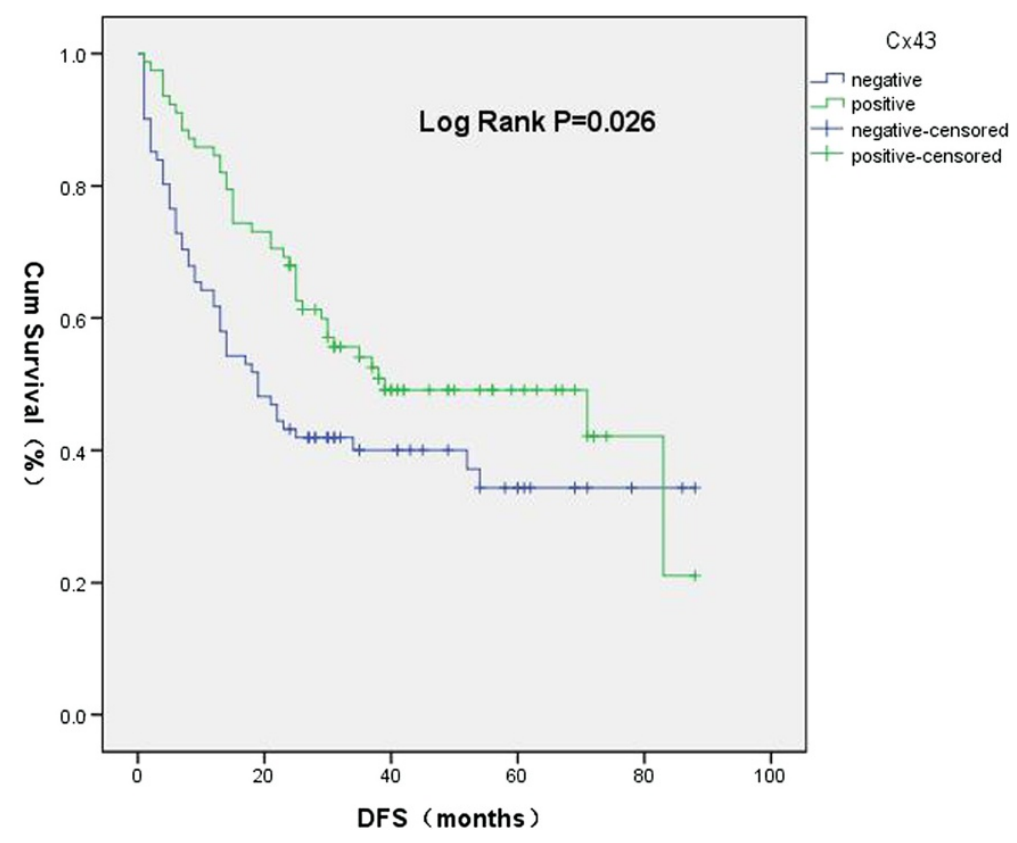

Figure 6 Disease-free survival curves. 


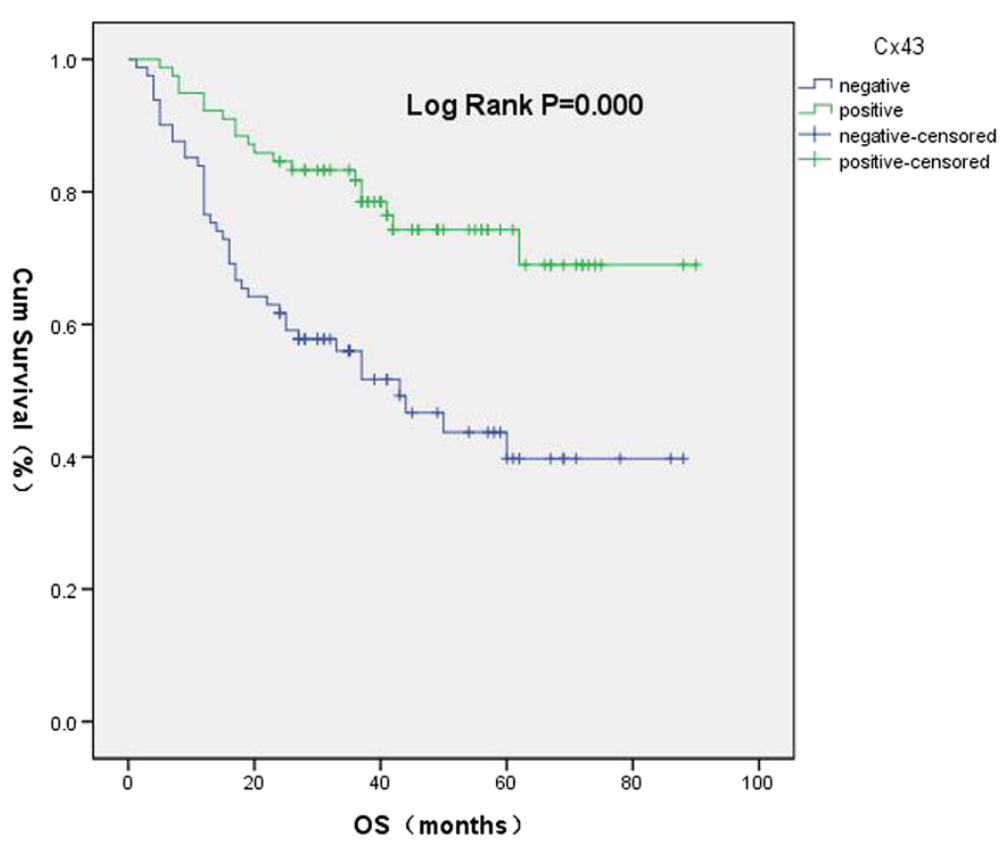

Figure 7 Overall survival curves.

capacity of these cells and restrained cancer cell growth [23]. Ogawa et al. established six rat HCC cell lines that exhibited different metastatic potentials after inoculation into the tail veins of nude mice and transfection of an siRNA targeting $C x 43$ (as shown by cDNA array analysis), indicating that suppression of $\mathrm{Cx} 43$ expression in tumor cells reduced in vitro migration and invasion capacity and in vivo metastatic ability [24].

Our results also showed that Cx43 expression in HCC tissue is inversely related to invasion and metastasis, expression of VEGF and CD105, and vascular tumor thrombosis. $\mathrm{Cx} 43$ is an independent predictor of later recurrence and longer OS after HCC radical hepatectomy. The RT-PCR results also showed that expression of $C x 43$ mRNA is related to later recurrence.

CD105-MVD reflects new vessel growth in HCC tissue and is an independent predictor of recurrence, metastasis, and vessel invasion in postoperative patients with $\mathrm{HCC}$
[25]. VEGF can substantially accelerate division and growth of vascular endothelial cells and angiogenesis. High VEGF levels can promote plasma protein exosmosis to induce fibrin deposition and new vessel generation, allowing invasion and metastasis; patients with HCC and higher VEFG expression in serum and HCC tissue have a poorer prognosis $[9,26]$.

Immunohistochemistry results showed higher expression of CD105 and VEGF in patients with lower Cx43 levels. The reason may be that impaired GJIC function is closely related to early tumor occurrence, invasion, and metastasis [17]. Cx43 expression in HCC tissue can improve intercellular GJIC and restrain expression of the tumor accelerator angiogenesis factor, thus reducing recurrence and metastasis. This result indicates that Cx43 expression in HCC tissue is inversely related to important factors of postoperative HCC recurrence, such as tumor differentiation $(P=0.002)$ and vascular tumor

Table 7 Cox regression analysis

\begin{tabular}{llccc}
\hline & & RR & 95.0\% Cl & P Value \\
\hline \multirow{2}{*}{ One-year recurrence } & Histological differentiation & 2.762 & $1.482-5.147$ & 0.001 \\
& Cx43 expression & 0.485 & $0.241-0.974$ & 0.042 \\
Disease-free survival & Vascular tumor thrombosis & 6.453 & $2.355-17.68$ & 0.000 \\
& Histological differentiation & 1.895 & $1.200-2.993$ & 0.006 \\
Overall survival & Vascular tumor thrombosis & 9.128 & $3.767-22.120$ & 0.000 \\
& Histological differentiation & 2.727 & $1.575-4.724$ & 0.000 \\
& Vascular tumor thrombosis & 15.906 & $5.990-42.239$ & 0.000 \\
\hline
\end{tabular}


thrombosis $(P=0.029)$, showing that $\mathrm{Cx} 43$ affects HCC recurrence and metastasis.

The present results indicate that patients with $\mathrm{Cx} 43^{+}$ HBV-HCC have a longer OS than do patients with $\mathrm{Cx} 43^{-}$HBV-HCC. In particular, patients with $\mathrm{Cx} 43^{+}$ HBV-HCC have better 1-year DFS and OS than do those with $\mathrm{Cx} 43^{-} \mathrm{HBV}-\mathrm{HCC}$ and low serum AFP levels.

\section{Conclusion}

This study demonstrated that $\mathrm{Cx} 43^{+}$expression in HBVHCC tissue is a predictor of lower early recurrence rates and better prognosis in patients with low serum AFP levels and could be significant in terms of improving individualized treatments.

\section{Abbreviations \\ HCC: Hepatocellular carcinoma; Cx43: Connexin-43; GJs: Gap junctions; GJIC: Gap junction intercellular communication; HBV: Hepatitis B virus; VEGF: Vascular endothelial growth factor; RT-PCR: Reverse transcription polymerase chain reaction; AFP: Alpha-fetoprotein; MVD: Microvessel density; $\mathrm{CT}$ : Computed tomography; MRI: Magnetic resonance imaging; ALB: Serum albumin; Tbil: Total bilirubin; ALT: Alanine transaminase; AST: Glutamic- oxalacetic transaminase; DFS: Disease-free survival; OS: Overall survival; HBV- HCC: Hepatitis B-related hepatocellular carcinoma; High AFP: Serum AFP of $\geq 400 \mu \mathrm{g} /$; Low AFP: Serum AFP of $<400 \mu \mathrm{g} / \mathrm{l}$. \\ Competing interests \\ The authors declare that they have no competing interests. \\ Authors' contributions \\ ZSW and LQW participated in the design of the experiments, data interpretation, and manuscript preparation. XY and CG contributed equally to this work. They performed the experiments, including immunohistochemistry and RT-PCR experiments; analyzed the data; and participated in the writing of the manuscript. YJL and RYY guided the immunohistochemistry and RT-PCR experiments and participated in the design of the experiments. All authors read and approved the final manuscript.}

\section{Acknowledgements}

We thank the Department of Pathology of Qingdao Municipal Hospital, who provided technique support of the tissue microarray.

\section{Author details}

${ }^{1}$ Department of Hepatobiliary Surgery, Affiliated Hospital of Medical College Qingdao University, Qingdao, Shandong Province 266003, China. ${ }^{2}$ Department of Pathology, Affiliated Hospital of Medical College Qingdao University, Qingdao, Shandong Province 266003, China. ${ }^{3}$ Department of Central Laboratory, Affiliated Hospital of Medical College Qingdao University, Qingdao, Shandong Province 266003, China.

Received: 24 December 2012 Accepted: 20 June 2013

Published: 24 June 2013

\section{References}

1. Ferlay J, Shin HR, Bray F, Forman D, Mathers C, Parkin DM: Estimates of worldwide burden of cancer in 2008: GLOBOCAN 2008. Int J Cancer 2010, 127(12):2893-2917.

2. Jemal A, Bray F, Center MM, Ferlay J, Ward E, Forman D: Global cancer statistics. CA Cancer J Clin 2011, 61(2):69-90.

3. Bruix J, Sherman M: Management of hepatocellular carcinoma. Hepatology 2005, 42(5):1208-1236.

4. Mazzaferro V, Regalia E, Doci R, et al: Liver transplantation for the treatment of small hepatocellular carcinomas in patients with cirrhosis. N Engl J Med 1996, 334(11):693-699.

5. Llovet JM, Burroughs A, Bruix J: Hepatocellular carcinoma. Lancet 2003, 362(9399):1907-1917.
6. Tung-Ping PR, Fan ST, Wong J: Risk factors, prevention, and management of postoperative recurrence after resection of hepatocellular carcinoma. Ann Surg 2000, 232(1):10-24.

7. Poon RT, Fan ST, Lo CM, Liu CL, Ng IO, Wong J: Long-term prognosis after resection of hepatocellular carcinoma associated with hepatitis B-related cirrhosis. J Clin Oncol 2000, 18(5):1094-1101.

8. Toyama T, Hiramatsu N, Yakushijin T, et al: A new prognostic system for hepatocellular carcinoma including recurrent cases: a study of 861 patients in a single institution. J Clin Gastroenterol 2008, 42(3):317-322.

9. Ariizumi S, Takasaki K, Yamamoto M, Ohtsubo T, Saito A, Nakano M: Multicentric hepatocellular carcinomas tend to grow in more damaged segments of the liver. J Gastroenterol 2000, 35(6):441-444.

10. Perz JF, Armstrong GL, Farrington LA, Hutin YJ, Bell BP: The contributions of hepatitis $B$ virus and hepatitis $C$ virus infections to cirrhosis and primary liver cancer worldwide. J Hepatol 2006, 45(4):529-538.

11. Han YF, Zhao J, Ma LY, et al: Factors predicting occurrence and prognosis of hepatitis-B-virus-related hepatocellular carcinoma. World J Gastroenterol 2011, 17(38):4258-4270.

12. Kojima T, Yamamoto M, Mochizuki C, Mitaka T, Sawada N, Mochizuki Y: Different changes in expression and function of connexin 26 and connexin 32 during DNA synthesis and redifferentiation in primary rat hepatocytes using a DMSO culture system. Hepatology 1997, 26(3):585-597.

13. Ara C, Massimi M, Devirgiliis CL: Retinoic acid modulates gap junctional intercellular communication in hepatocytes and hepatoma cells. Cell Mol Life Sci 2002, 59(10):1758-1765.

14. Weidner N, Semple JP, Welch WR, Folkman J: Tumor angiogenesis and metastasis-correlation in invasive breast carcinoma. N Engl J Med 1991, 324(1):1-8.

15. Tang ZY, Ye SL, Liu YK, et al: A decade's studies on metastasis of hepatocellular carcinoma. J Cancer Res Clin Oncol 2004, 130(4):187-196.

16. Poon RT, Fan ST, Ng IO, Lo CM, Liu CL, Wong J: Different risk factors and prognosis for early and late intrahepatic recurrence after resection of hepatocellular carcinoma. Cancer 2000, 89(3):500-507.

17. Mesnil M, Crespin S, Avanzo JL, Zaidan-Dagli ML: Defective gap junctional intercellular communication in the carcinogenic process. Biochim Biophys Acta 2005, 1719(1-2):125-145.

18. Loewenstein WR, Kanno Y: Intercellular communication and tissue growth. I. Cancerous growth. J Cell Biol 1967, 33(2):225-234.

19. Loewenstein WR, Kanno $Y$ : Intercellular communication and the control of tissue growth: lack of communication between cancer cells. Nature 1966, 209(5029):1248-1249.

20. Trosko JE: The role of stem cells and gap junctional intercellular communication in carcinogenesis. J Biochem Mol Biol 2003, 36(1):43-48.

21. Tangkijvanich P, Anukulkarnkusol N, Suwangool P, et al: Clinical characteristics and prognosis of hepatocellular carcinoma: analysis based on serum alpha-fetoprotein levels. J Clin Gastroenterol 2000, 31(4):302-308.

22. Ma XD, Sui YF, Wang WL: Expression of gap junction genes connexin 32, connexin 43 and their proteins in hepatocellular carcinoma and normal liver tissues. World J Gastroenterol 2000, 6(1):66-69.

23. Ionta M, Ferreira RA, Pfister SC, Machado-Santelli GM: Exogenous Cx43 expression decrease cell proliferation rate in rat hepatocarcinoma cells independently of functional gap junction. Cancer Cell Int 2009, 9:22.

24. Ogawa K, Pitchakarn P, Suzuki S, et al: Silencing of connexin 43 suppresses invasion, migration and lung metastasis of rat hepatocellular carcinoma cells. Cancer Sci 2012, 103(5):860-867.

25. Yang LY, Lu WQ, Huang GW, Wang W: Correlation between CD105 expression and postoperative recurrence and metastasis of hepatocellular carcinoma. BMC Cancer 2006, 6:110.

26. Poon RT, Ng IO, Lau C, et al: Serum vascular endothelial growth factor predicts venous invasion in hepatocellular carcinoma: a prospective study. Ann Surg 2001, 233(2):227-235.

doi:10.1186/1471-2407-13-306

Cite this article as: Wang et al:: Connexin- 43 can delay early recurrence and metastasis in patients with hepatitis B-related hepatocellular carcinoma and low serum alpha-fetoprotein after radical hepatectomy. BMC Cancer 2013 13:306. 